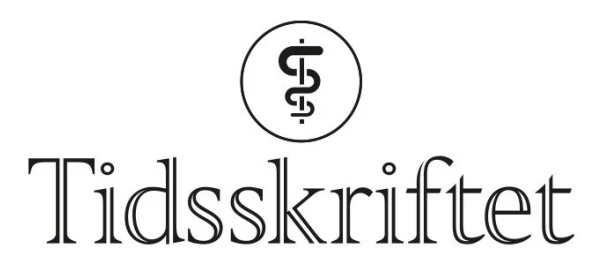

DEN NORSKE LEGEFORENING

\title{
En mann i 8o-årene med gangvansker og høy CRP-verdi
}

NOE Å LARE AV

\author{
ÅSE BERG \\ ase.berg@sus.no \\ Infeksjonsmedisinsk seksjon \\ Stavanger universitetssjukehus \\ Åse Berg er ph.d. og spesialist i indremedisin og i infeksjonsmedisin. \\ Forfatteren har fylt ut ICMJE-skjemaet og oppgir ingen interessekonflikter.
}

\section{HERMAN DOELAND}

Tau legesenter

Herman Doeland er spesialist i allmennmedisin og fastlege.

Forfatteren har fylt ut ICMJE-skjemaet og oppgir ingen interessekonflikter.

\section{HILDE FARDAL}

Avdeling for medisinsk mikrobiologi

Stavanger universitetssjukehus

Hilde Fardal er LIS3-lege.

Forfatteren har fylt ut ICMJE-skjemaet og oppgir ingen interessekonflikter.

\section{EVEN FLØRENAES}

Analyseavdelingen

Stavanger universitetssjukehus

Even Flørenæs har mastergrad i medisinsk signalbehandling og er analytiker.

Forfatteren har fylt ut ICMJE-skjemaet og oppgir ingen interessekonflikter.

\section{ESPEN ØGL/END BJØRNESTAD}

Mottaksklinikken

Stavanger universitetssjukehus

Espen Øglænd Bjørnestad er LIS2-lege.

Forfatteren har fylt ut ICMJE-skjemaet og oppgir ingen interessekonflikter.

\section{ANITA SANDMO LYNGØY}

Mottaksklinikken

Stavanger universitetssjukehus

Anita Sandmo Lyngøy er spesialist i indremedisin og i infeksjonsmedisin.

Forfatteren har fylt ut ICMJE-skjemaet og oppgir ingen interessekonflikter. 


\section{En mann i 8o-årene ble innlagt på grunn av redusert allmenntilstand, nyoppståtte balanse- og gangvansker og høy CRP-verdi. Et overraskende prøvesvar ved innkomst kunne fått alvorlige følger.}

En til vanlig sprek mann tidlig i 8o-årene fikk i løpet av få uker balanse- og gangproblemer. En uke før han kom til fastlegen hadde han falt hjemme uten medfølgende svimmelhet eller hjertebank. Symptomene forverret seg, og på kvelden før konsultasjonen klarte han ikke å reise seg uten hjelp og hadde et nytt fall. Han hadde ikke kraftsvikt eller talevansker, og kona la ikke merke til skjevhet $i$ ansiktet. I samråd med legevakten gikk han til fastlegen neste dag.

Der kom han inn med små skritt og med støtte av stav. Han virket uttalt slapp sammenlignet med tidligere. Det var ikke symptomer fra luftveier, mage eller urinveier. Fra tidligere hadde han mangeårig polynevropati, velregulert type 2-diabetes ved bruk av metformin og empagliflozin, og han brukte propranolol mot tremor. På grunn av hypertensjon tok han enalapril/hydroklortiazid og på grunn av atrieflimmer flekainid og warfarin. Fire år tidligere hadde han fått diagnostisert polymyalgia rheumatica, og prednisolon var blitt seponert etter to år. Formen hans hadde vart god inntil det aktuelle. Han hadde ikke startet med nye medikamenter og kom regelmessig til INRkontroll.

Ved relativt raskt økende balanseproblemer og falltendens hos eldre må man først tenke på en nevrologisk årsak, medikamentbivirkninger, anemi, infeksjoner og hyperglykemi.

Ved undersøkelse hos fastlegen virket han svekket og gusten i ansiktet, men klar og orientert for tid og sted. Pulsen var 70 slag/minutt, blodtrykket 112/66 mm Hg, temperaturen $37{ }^{\circ} \mathrm{C}$ i øret og oksygenmetningen 96 \% på romluft. Nevrologisk undersøkelse viste sidelike pupiller med normal reaksjon på lys, ingen pareser, sidelike patella- og akillessenereflekser og ingen nystagmus. Rombergs test var negativ. Blodprøver viste hemoglobin 14,5 g/dL (referanseområde 13,4-17,o), B-glukose 10,2 mmol/L (4,o-6,o, fastende) og CRP $155 \mathrm{mg} / \mathrm{L}$ (<5). Urinstiks viste utslag på glukose $4^{+}$. Klinisk undersøkelse viste ingen tegn til nevrologisk årsak. Pasienten var afebril og uten spesifikke infeksjonssymptomer. Blodprøvene viste ingen anemi, lett økt glukose og forhøyet CRP-verdi. Hans reduserte allmenntilstand og raskt utviklede funksjonssvikt krevde videre utredning.

Pasienten ble innlagt på sykehus for øyeblikkelig hjelp. I akuttmottaket opplyste han selv at han sannsynligvis hadde falt på grunn av sin polynevropati. Han benektet bevissthetstap, hjertebank, kraftsvikt eller slag mot hodet. Ved undersøkelse fant man en slank mann i lett svekket allmenntilstand. Han var orientert, men svarte med noe latenstid. Han var tørr og varm $i$ huden, med blodtrykk 135/89 mm Hg og puls 75 slag/minutt. Han hadde respirasjonsfrekvens 22/minutt og oksygenmetning $96 \%$ på romluft. Ved auskultasjon hørte man uregelmessig hjerteaksjon uten bilyder og fine inspiratoriske knatrelyder basalt på begge lungene. Gangen var litt ustø, men uten falltendens til noen bestemt side. Øvrig klinisk og orienterende nevrologisk unders $\emptyset$ kelse var upåfallende.

Arteriell blodgass på romluft viste $\mathrm{pH}$ 7,47 (7,35-7,45), $\mathrm{pO}_{2}$ 10,5 $\mathrm{kPa}(>10,7), \mathrm{pCO}_{2} 4,4 \mathrm{kPa}(4,5-6,0)$, $\mathrm{HCO}_{3}-25,1 \mathrm{mmol} / \mathrm{L}(22-26)$, oksygenmetning $97 \%$ (> 94) og laktat o,8 mmol/L (o,3-1,8). Øvrige blodprøver viste leukocytter på 16,6 $\cdot 10^{9} / \mathrm{L}(3,9-9,8)$, nøytrofile granulocytter på 13,6 $\cdot 10^{9} / \mathrm{L}(1,7-6,3)$ og monocytter på 1,51 $\cdot 10^{9} / \mathrm{L}(0,26-0,90)$. Han var lett anemisk med hemoglobin $12,8 \mathrm{~g} / \mathrm{dL}(13,2-16,5)$, hadde INR 3,1 (2,0-3,o ved atrieflimmer), lett forhøyet urinstoff 11,5 mmol/L (3,5-8,1), B-glukose 10,6 mmol/L (4,0-6,o, fastende) og forhøyet CRP på $194 \mathrm{mg} / \mathrm{L}$ (<5). Øvrige laboratorieverdier var normale. 
Røntgen av lungene viste kjente utstrakte bilaterale pleuraplakk og et mulig nyoppstått infiltrat medialt på høyre side. Hals- og nasofarynksprøve analysert med polymerasekjedereaksjon (PCR)hurtigtest $i$ akuttmottaket var positiv for SARS-CoV-2 og negativ for influensavirus $A$ og $B$.

Selv om pasienten ikke var vaksinert mot covid-19, oppfattet legen i akuttmottaket sykehistorien som atypisk for covid-19-infeksjon på grunn av manglende luftveissymptomer, høy CRP-verdi, leukocytose og nøytrofili. Typiske symptomer ved covid19 er feber, tørrhoste, tungpustethet og slapphet. Mindre hyppig er kvalme, oppkast, diaré, hodepine, rennende nese, svimmelhet og tap av lukte- og smakssans $(\underline{1}, \underline{2})$. Eldre har ofte færre symptomer og sjeldnere feber og hoste (3-5). Tilstanden ble oppfattet som akutt covid-19-luftveisinfeksjon med mulig bakteriell superinfeksjon, alternativt en annen bakteriell infeksjon i tillegg.

Det ble bedt om urinstiks, som viste protein+, glukose $4+$ og blod+. Pasienten ble lagt inn på pandemipost og kohortisolert sammen med to andre pasienter med bekreftet covid-19-infeksjon. Han fikk benzylpenicillin $1,2 \mathrm{~g} \times 4$ intravenøst. På kveldsvisitten samme dag klaget han over svimmelhet og hukommelsesproblemer. Han som vanligvis husket alle medisinene sine, gjorde ikke det nå. Ved ny vurdering var nevrologisk status normal, og han gikk relativt greit over gulvet med gåstol. Supplerende blodprøver tatt etter innleggelse viste senkningsreaksjon på $83 \mathrm{~mm}(<20)$ og prokalsitonin $0,13 \mu g / L(<0,10)$.

Da fastlegen ble informert om covid-19-diagnosen, sa han at pasienten hadde hatt minimal kontakt med andre de siste to ukene. Han hadde vanskelig for å tro at diagnosen var korrekt, men gikk likevel i karantene som nærkontakt. Kona til pasienten ringte avdelingen gjentatte ganger og sa at det måtte være feil at mannen hadde covid-19, siden han ikke hadde vært i kontakt med noen andre enn henne og fastlegen.

Dagen etter innleggelsen var han klarnet helt opp mentalt. En sykepleier med god erfaring $i$ å ta covid-19-test, tok en ny hals- og nasofarynksprøve som ble sendt til polymerasekjedereaksjonsanalyse på mikrobiologisk avdeling. Denne prøven var negativ for SARS-CoV-2. Pasienten ble tatt ut av kohortisolasjonen og lagt på eneisolat i påvente av avklaring. Analysemaskinen i mottaket som man mistenkte ga falskt positivt resultat, ble umiddelbart tatt ut av rutinedrift. Primcerprøven ble retestet på samme analysemaskin samt med PCR-hurtigtest fra en annen leverandør og egenvalidert PCR på mikrobiologisk avdeling. Retestene ogytterligere én prøve tatt to dager etter innleggelse viste samme resultat: SARS-CoV-2-RNA ikke påvist.

SARS-CoV-2 påvises direkte ved polymerasekjedereaksjon. Det skjer ved at arvestoffet $\mathrm{i}$ prøven ekstraheres og renses, slik at utvalgte deler av SARS-CoV-2 kan kopieres opp til påviselige mengder ved polymerasekjedereaksjon. Ved sanntids-PCR måles oppkopiert PCR-produkt for hver syklus, og påvist PCR-produkt vises grafisk som en sigmoid (S-formet) amplifikasjonskurve. Første syklus med påvist signal som er signifikant høyere enn bakgrunnsstøyen, kalles syklusterskel (cycle threshold, CT) (figur 1). CT-verdien er omvendt proporsjonal med mengde virus i prøven, slik at en lav CT-verdi tilsvarer høyere virusmengde enn en høy CT-verdi. Dersom det ikke er virus til stede i prøven, skal det ikke dannes påviselig PCR-produkt, og amplifikasjonskurven forblir flat. 


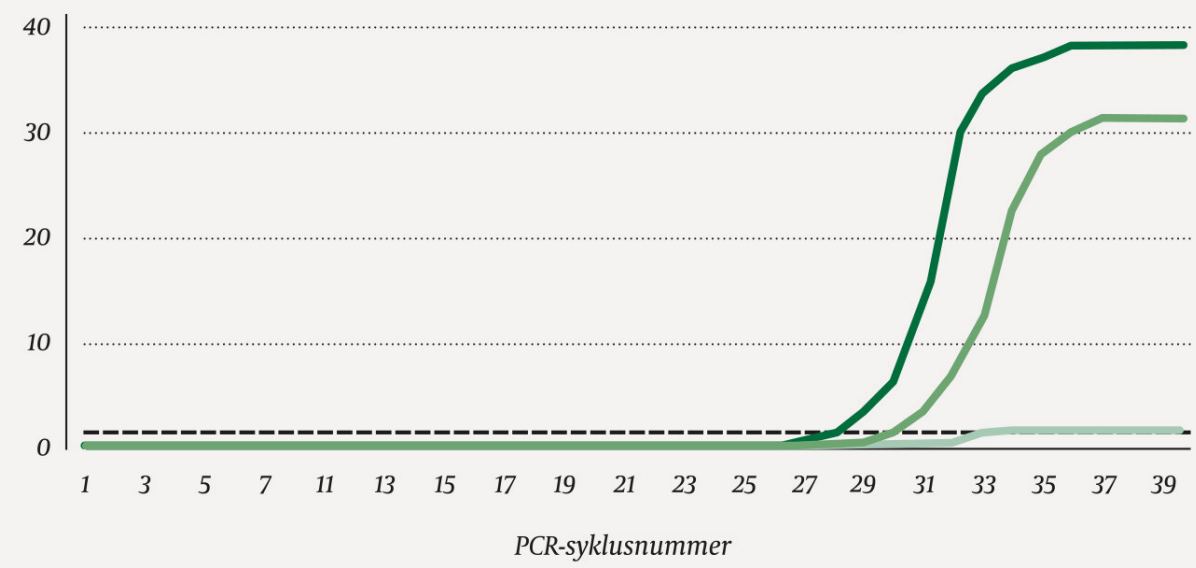

Figur 1 Skjematisk framstilling av amplifikasjonsplot ved PCR-analyse. Kurven for positiv pasientprøve er eksempel på en pasientprøve der SARS-CoV-2 påvises. Virusets arvestoff blir oppkopiert og det dannes en sigmoidformet amplifikasjonskurve. Syklusterskelen definerer grense mellom positivt og negativt analyseresultat. Pasientprøven er positiv etter om lag 30 PCR-sykler. Amplifikasjonskurven til den aktuelle pasienten krysser så vidt syklusterskelen etter 33 PCR-sykler, men den sigmoide formen på amplifikasjonskurven mangler, og PCR-maskinen tolket analysen feilaktig som påvist SARS-CoV-2.

PCR-testing tilbys både gjennom laboratorienes egenvaliderte analyser (in-house PCR) og ferdige, kommersielle plattformer. I tillegg tilbyr kommersielle aktører ulike PCRhurtigtester i form av black box-systemer, hvor prøvematerialet tilsettes direkte i en ferdiglaget analysekassett som inneholder alle nødvendige reagenser. I disse systemene er analyseprosessen vanligvis ikke tilgjengelig fra produsent, og resultatet tolkes kvalitativt som positivt eller negativt av en programvare. Amplifikasjonskurver og CT-verdier er lite/ikke tilgjengelig for brukeren.

PCR-hurtigtester har flere fordeler: Analysetiden er kun 20-45 minutter (-9-9), prøvene analyseres fortløpende, prosessen er helautomatisert og maskinen gir et analysesvar uten at brukeren trenger å tolke CT-verdi og amplifikasjonskurver. Analysen krever minimalt med opplæring og markedsføres for bruk utenfor laboratoriets lokaler $(\underline{6}, \underline{8})$. Til sammenligning har egenvaliderte PCR-tester en analysetid på 3-4 timer, flere prøver samles ofte opp før start for å utnytte analysekapasiteten, analysen må utføres på laboratoriet av spesialopplært laboratoriepersonell, og tolkning av CT-verdier og amplifikasjonskurver må gjøres før resultatet kan rapporteres til rekvirent.

Pasient, ektefelle, sønn, fastlege og smittevernoverlege i kommunen ble informert med stor beklagelse om feilen som var skjedd. Hendelsen ble meldt i sykehusets avvikssystem, og det ble sendt melding til Helsetilsynet om alvorlig hendelse (spesialisthelsetjenesteloven $\S_{3}-3$ ). Slik melding skal sendes ved dødsfall eller betydelig skade på pasient der utfallet er uventet ut fra påregnelig risiko. I denne saken valgte man å sende melding til Helsetilsynet før det var avklart om pasienten var påført skade/smitte, med bakgrunn $i$ svcert høyt skadepotensial og den spesielle situasjonen med pågående pandemi, der åpenhet rundt avvik er helt nødvendig for lcering og forbedring.

Benzylpenicillin ble seponert etter fem døgn og erstattet med prednisolon $40 \mathrm{mg}$ daglig ut fra mistanke om tilbakefall av polymyalgia rheumatica, da pasienten hadde smerter i kroppen, høy CRP og høy senkningsreaksjon uten holdepunkt for annen infeksjon. I tillegg fikk han fysioterapi. Han ble utskrevet etter seks døgns observasjon. Gjentatte hals- og nasofarynksprøver tatt dag 4, 6, $12 \mathrm{og}$ 17 etter kohortisoleringen var negative for SARS-CoV-2-RNA, og SARS-CoV-2-antistoff (IgM og IgG) ble ikke påvist 26 dager etter smitteeksponering. Pasienten ble raskt bedre etter igangsatt behandling 
med prednisolon. Senkningsreaksjonen var $15 \mathrm{~mm}$ og CRP-verdien $9 \mathrm{mg} / \mathrm{L}$ ved kontroll etter ytterligere tre uker. Ved kontroll hos fastlegen fem måneder etter utskrivning var han tilbake til sitt tidligere funksjonsnivå, fortsatt med bruk av prednisolon $5 \mathrm{mg}$ daglig.

\section{Diskusjon}

Hos denne pasienten ble covid-19-diagnosen primært basert på resultatet av en PCRhurtigtest uten at fagpersonell med laboratoriekompetanse vurderte prøvens CT-verdi eller amplifikasjonskurve. Takket være pasienten selv, som sa at «det er ikke noe korona i denne kroppen», der han lå i samme rom som to andre covid-19-pasienter, og ikke minst mange telefoner fra kona om at prøveresultatet måtte være feil, ble testen gjentatt. Atypiske kliniske funn, manglende smitteeksponering og negativt resultat ved retest samt analyse av ytterligere prøver, avkreftet diagnosen.

Ved feilsøking i etterkant av hendelsen ble CT-verdi og kurve fra den falskt positive prøven hentet ut fra hurtigtestmaskinen (figur 1). Den sigmoidformede amplifikasjonskurven som skal dannes ved påvist PCR-produkt, var ikke til stede, og prøven ville blitt rapportert som negativ for SARS-CoV-2 dersom kvalifisert fagpersonell hadde vurdert resultatet. Produsenten ble kontaktet, og det foreligger ingen god forklaring på hvorfor maskinen feiltolket den aktuelle prøven.

Laboratorieanalyser har ulik grad av presisjon, og både falskt positive og falskt negative testresultater vil forekomme. Dette gjelder også for analyser som er gode til å avsløre om en person er syk eller frisk, det vil si tester med henholdsvis høy sensitivitet (som uttrykker sannsynligheten for en positiv test hos en smittet person) og spesifisitet (som uttrykker sannsynligheten for negativ test hos en person som ikke er smittet). Å kunne si noe om hvor sannsynlig det er at testresultatet er korrekt (prediktiv verdi), er dermed viktig for videre håndtering av situasjonen. For å beregne prediktiv verdi må testresultatet ses $\mathrm{i}$ sammenheng med sykdomsforekomsten (prevalensen) $i$ området analysen anvendes. Ved lav prevalens vil en høyere andel av positive resultater være falskt positive (므). Hvis prevalensen endres raskt, som ved et utbrudd, øker sannsynligheten for sanne positive testresultat.

Smitterisiko for den enkelte pasient må også tas med i beregningen. Eksempelvis vil forekomsten av covid-19 være lav hos pasienter med fa (ikke-smittede) nærkontakter. I en slik situasjon vil det være større sjanse for at et positivt svar er falskt positivt enn dersom personen har mange nærkontakter. Kombineres dette utgangspunktet med et uventet prøveresultat, blir det ekstra viktig at kliniker vurderer prøvesvaret kritisk og at prøven gjentas ved mistanke om falskt positivt svar. Selv om falskt negative prøvesvar er vesentlig mindre sannsynlig med PCR-baserte hurtigtester, er det tilsvarende viktig at kliniker vurderer å ta ny test ved sterk klinisk mistanke og negativt svar.

Som konsekvens av denne hendelsen har vårt sykehus endret rutinene. Ved påvist SARSCoV-2 på PCR-hurtigtest legges pasienten på eneisolat mens prøvesvaret bekreftes med en egenvalidert PCR-test på mikrobiologisk avdeling før pasienten legges inn i kohortenhet med andre smitteførende pasienter. På denne måten påføres ikke pasienten unødvendig risiko, og konsekvensen av et eventuelt falskt positivt prøvesvar minimeres. Gevinsten av raske svar ved å utføre PCR-hurtigtest i akuttmottak med tanke på både pasientsikkerhet og ressursbruk vurderes fortsatt som betydelig større enn risikoen ved et falskt positivt prøvesvar.

Pasienten hargitt samtykke til at artikkelen blir publisert. Artikkelen er fagfellevurdert. 


\section{LITTERATUR}

1. Wiersinga WJ, Rhodes A, Cheng AC et al. Pathophysiology, transmission, diagnosis, and treatment of coronavirus disease 2019 (COVID-19): A review. JAMA 2020; 324: 782-93. [PubMed][CrossRef]

2. Mao L, Jin H, Wang M et al. Neurologic manifestations of hospitalized patients with coronavirus disease 2019 in Wuhan, China. JAMA Neurol 2020; 77: 683-90. [PubMed][CrossRef]

3. Unim B, Palmieri L, Lo Noce $C$ et al. Prevalence of COVID-19-related symptoms by age group. Aging Clin Exp Res 2021; 33: 1145-7. [PubMed][CrossRef]

4. Al-Mudhaffer RH, Ahjel SW, Hassan SM et al. Age distribution of clinical symptoms, isolation, comorbidities and case fatality rate of COVID-19 Cases in Najaf City, Iraq. Med Arh 2020; 74:363-7. [PubMed][CrossRef]

5. Xie Y, Wang Z, Liao H et al. Epidemiologic, clinical, and laboratory findings of the COVID-19 in the current pandemic: systematic review and meta-analysis. BMC Infect Dis 2020; 20: 640. [PubMed] [CrossRef]

6. Roche D. cobas® SARS-CoV-2 \& Influenza A/B Assay 2021.

https://diagnostics.roche.com/global/en/products/params/cobas-sars-cov-2-influenza-a-b-nucleicacid-test.html\#productInfo/ Lest 12.3.2021.

7. Cepheid. GeneXpert, Xpert@ Xpress SARS-CoV-2/Flu/RSV 2021. https://www.cepheid.com/coronavirus/ Lest 12.3.2021.

8. Bosch. Vivalytic SARS-CoV-2 2021. https://www.bosch-vivalytic.com/en/product/vivalytic-tests/pcrtest-for-sars-cov-2/ Lest 12.3.2021.

9. BioMérieux. BIOFIRE® FILMARRAY@ Respiratory Panel 2.1 plus. https://www.biomerieuxdiagnostics.com/filmarrayr-respiratory-panel/ Lest 12.3.2021.

10. Lydersen S. Hva er sannsynligheten for riktig resultat av en diagnostisk test? Tidsskr Nor Legeforen 2017; 137. doi:10.4045/tidsskr.17.0409. [PubMed][CrossRef]

Publisert: 30. september 2021. Tidsskr Nor Legeforen. DOI: 10.4045/tidsskr.21.0240

Mottatt 25.3.2021, første revisjon innsendt 28.1.2021, godkjent 14.9.2021.

Publisert under åpen tilgang CC BY-ND. Lastet ned fra tidsskriftet.no 26. april 2023. 